\title{
LEFT ATRIAL LONGITUDINAL STRAIN EVALUATED BY 2D SPECKLE TRACKING ECHOCARDIOGRAPHY CAN IDENTIFY PATIENTS WITH HEART FAILURE WITH PRESERVED EJECTION FRACTION
}

\author{
Mihaela Bolog, Mihaela Dumitrescu, Luminița Mârzan, Florentina Romanoschi, \\ Elena Păcuraru, Alina Râpă \\ Prof. Dr. Agrippa Ionescu Emergency Clinical Hospital \\ Department of Internal Medicine \\ Corresponding author: Mihaela Ioana Bolog \\ email: mihaela.bolog@gmail.com
}

\section{Abstract}

The aim of the paper is to investigate the utility of left atrial longitudinal strain (LALS) in the diagnosis of heart failure with preserved ejection fraction (HFpEF) when left ventricular diastolic function is indeterminable and the assessment of natriuretic peptides is not routinely performed.

Method. The study included 180 patients with signs and symptoms suggestive of non-acute heart failure, examined clinically and echocardiographically, both conventionally and via speckle tracking method.

Results. 33 patients had a normal echocardiographic examination. Diastolic dysfunction (DD) was present in 116 patients of whom 32 patients had grade I, 66 patients grade II, 18 patients grade III DD. Diastolic function could not be determined in 31 patients. The mean value of LALS and NTproBNP in patients with normal echocardiography was significantly different from the group with $D D$ for both variables $(p<0.001)$. LALS was inversely correlated with the grade of $D D(r=-0.83, p<0.001)$. The cut-off value of LALS for predicting DD was $25 \%$. Applying this value in patients with indeterminate diastolic function we identified 21 patients with HFpEF $(p<0.001)$.

Conclusions. LALS can help in the diagnosis of HFpEF when other echocardiographic criteria are irrelevant and NTproBNP is not routinely performed. LALS was correlated with the presence and severity of DD with a cut-off value of $25 \%$.

Key words: left atrial longitudinal strain, echocardiography. 


\section{INTEH}

\section{Rezumat}

Scopul lucrării este de a investiga utilitatea strain-ului atrial stâng longitudinal (SASL) în diagnosticul insuficienței cardiace cu fracție de ejecție păstrată (ICFEP) atunci când funcția diastolică a ventriculului stâng este nedeterminabilă și evaluarea peptidelor natriuretice nu se efectuează de rutină.

Metodă. Studiul a inclus 180 de pacienți cu semne și simptome sugestive pentru insuficiență cardiacă non acută, examinați clinic și ecocardiografic convențional și prin metoda speckle tracking.

Rezultate. Un număr de 33 de pacienți au prezentat examen ecocardiografic normal. Disfuncție diastolică (DD) au prezentat 116 pacienți, dintre care 32 pacienți aveau grad I, 66 pacienți grad II, 18 pacienți grad III. Funcția diastolică nu a putut fi determinată la 31 de pacienți. Valoarea medie a SASL și NTproBNP la pacienții cu ecocardiografie normală a fost semnificativ diferită de cea a grupului cu DD pentru ambele variabile $(p<0,001)$. SASL a fost invers corelat cu gradul DD ( $r=-0,83, p<0,001)$. Valoarea cut-off a SASL pentru predicția $D D$ a fost 25\%. Aplicând această valoare pacienților cu funcție diastolică nedeterminată am identificat 21 pacienți cu ICFEP $(p<0,001)$.

Concluzii. SALS poate contribui la diagnosticul ICFEP atunci când alte criterii ecocardiografice sunt nerelevante și NTproBNP nu se efectuează de rutină. SASL s-a corelat cu prezența și severitatea DD cu o valoare cut-off de $25 \%$.

Cuvinte cheie: strain atrial stâng longitudinal, ecocardiografie. 


\section{INTRODUCTION}

Heart failure with preserved ejection fraction (HFpEF) is an entity defined by characteristic signs and symptoms, ejection fraction (EF) $\geq$ $50 \%$, increased values of natriuretic peptides, the presence of structural changes of the heart (left ventricular hypertrophy and/or left atrial enlargement) and/or left ventricular diastolic dysfunction ${ }^{(1)}$. The diagnosis of HFpEF is more difficult than the diagnosis of heart failure with reduced ejection fraction (HFrEF) $(E F<40 \%)$ due to the fact that the clinical presentation is nonspecific, natriuretic peptides can also be influenced by other conditions, the key parameter for the diagnosis - i.e. the ejection fraction - is normal, the structural anomalies of the heart can lack at standard echocardiographic examination, and left ventricular diastolic function assessed via echochardiography according to ASE/EACVI ${ }^{(2)}$ recommendations can be indeterminable (Figure 1 and 2 ).

Assessment of atrial deformation parameters is a promising method for atrial mechanics analysis.

The speckle tracking method of echocardiographic assessment allows the quantification of myocardial deformation via $2 \mathrm{D}$ and/or 3D exploration. The advantage is represented by the fact that it is independent of the exploration angle, unlike the Doppler method, it is less influenced by reverberations, side lobe phenomenon or dropout $^{(3)}$.

In contrast with left ventricular global longitudinal strain, atrial strain is not validated in the present, and the indexed volume of the left atrium is the main parameter for the assessment of atrial remodelling and for cardiac prognosis.

The purpose of our study is to investigate the utility of left atrial longitudinal strain in the diagnosis of HFpEF when left ventricular diastolic function is indeterminable and the assessment of natriuretic peptides is not routinely performed.

\section{METHOD}

The study included patients with signs and symptoms suggestive of heart failure: dyspnea on moderate/intense exertion, fatigability, lower limb edemas. Patients were examined clinically and echocardiographically. Patients with acute coronary syndromes, severe valvulopathies, cardiomyopathies, severe arrhythmias, class IV symptoms and/or ejection fraction $<50 \%$ were excluded.

\section{Standard 2D echocardiography}

Left ventricular systolic and diastolic function was assessed via 2D echocardiography and Doppler examination.

The echocardiographic examination was performed with a Philipps Epiq $7 G$ echograph, 4-2 $\mathrm{MHz}$ probe. The atrial and ventricular sizes were measured, also the ejection fraction via the Simpson method, the indexes of diastolic dysfunction according to recommendations ${ }^{2}$.

The atrial volume was indexed to the body surface area. By pulsed Doppler examination with placing of the sample at tip of the mitral valves, the $\mathrm{E}$ wave and the $\mathrm{A}$ wave were determined in proto-diastole and telediastole, respectively. Tricuspid regurgitation was assessed via continuous Doppler examination with the sample placed parallel with the direction of the jet. The section offering the peak regurgitation velocity was chosen. The cases where tricuspid regurgitation could not be interrogated correctly (difficult echographic image) were noted. 


\section{INTERNAI}

\section{Original papers}

\section{Tissue Doppler examination}

The assessment of the left ventricular longitudinal function was performed by placing the exploration sample at the level of the mitral annulus, septally and laterally. The septal and lateral proto-diastolic waves were measured (septal E' and lateral E'). For each examination the average of the $E^{\prime}$ wave was calculated (septal $E^{\prime}+$ lateral $E^{\prime} / 2$ ). Also the values of average E/E'was calculated.

\section{D speckle tracking echocardiography}

The atrial reservoir function was assessed by 2D speckle tracking method via the analysis of peak atrial longitudinal strain, using the $R$ wave as a reference and the model with 15 segments analysed in apical 4, 2 and 3 chamber view, excluding the anteroseptal segments corresponding to the aortic wall (Figure 3). The tracking was adjusted manually. The framerate was adjusted between 60-80 frames/second. The analysis was performed offline by the physician who performed the echocardiographies. In absence of a dedicated program we have adapted the software of the calculation of the ventricular global longitudinal strain for the determination of the atrial strain, after establishing the atrial fiducial points. The zero line was adapted to the atrial curves. Tracing of the atrial endocardium was performed automatically, with manual correction when the automatic tracing was incorrect. Peak atrial longitudinal strain was measured at the end of the reservoir phase (Figure 3), using the $\mathrm{R}$ wave as a reference, and was calculated automatically by averaging the values obtained in all segments.

Determination of NTproBNP was performed by the electrochemiluminescence immunoassay (ECLIA) method ${ }^{2}$. The cut-off value for heart failure was $125 \mathrm{pg} / \mathrm{mL}^{(1)}$.

\section{Statistic analysis}

The obtained data were expressed as mean values \pm standard deviations. The value $p<0.05$ was considered as statistically significant. The relationship between the continuous variables was calculated using the Pearson's correlation coefficient. The comparison between the means of two groups with continuous variables was performed using the Student's t-test, and for the categorical variables using $\chi^{2}$ and between the means of several groups using the ANOVA analysis.

\section{RESULTS}

\section{Characteristics of the study population}

180 patients were selected, 94 females, mean age $65 \pm 11$ years. 33 patients (18.3\%) had a normal echocardiographic examination; 116 patients (64.4\%) had diastolic dysfunction, 
and 31 patients (17.2\%) had indeterminate diastolic function. Demographic data did not differ significantly regarding age, female/male ratio, and body mass index (Table 1). In the group with patients with altered echocardiographic examination, the incidence of diabetes mellitus, hypertension, ischemic coronary artery disease, and history of atrial fibrillation was significantly higher compared to the group with normal echocardiographic examination $(p<0.001)$. Patients with diastolic dysfunction and indeterminate diastolic function had an ejection fraction significantly lower compared to those with normal echocardiographic examination $(p<0.05)$.

\section{Diastolic dysfunction}

The diagnosis of diastolic dysfunction was established according to the ASE / EACVI criteria $^{(2)}$ (Figure 1). Subsequently, patients with DD were divided according to the algorithm showed in Figure 2 in three subgroups: grade I - 32 patients (27.5\%), grade II - 66 patients (56.8\%), and grade III 18 patients (15.5\%), respectively (Table 2 ). Diastolic dysfunction and/or its grade could not be determined in 31 patients (17.2\%) for the following reasons: 21 cases - presence of two criteria out of four criteria of diastolic dysfunction (18 cases with criteria 2 and 4, and 3 cases with criteria 3 and 4 present, see Figure 1). In 10 cases, only three criteria of diastolic dysfunction could be analysed due to inadequate echocardiographical image (in 7 cases the tricuspid regurgitation could not be interrogated correctly, and in three cases the correct alignment for tissue Doppler could not be obtained).

\section{Results of the determination of NTproBNP}

The mean value of NTproBNP was significantly different in the group of patients with diastolic dysfunction compared to the group with normal echocardiographic examination (332 $\pm 54 \mathrm{pg} / \mathrm{mL}$ vs $117 \pm 4.7 \mathrm{pg} / \mathrm{mL}(p<0.05)$. The mean values of NTproBNP corresponding to subgroups with grade I, II and III of diastolic dysfunction (Table 2) were $224 \pm 5.1 \mathrm{pg} / \mathrm{mL}$, $311 \pm 8.9 \mathrm{pg} / \mathrm{mL}$, and $526 \pm 3.8 \mathrm{pg} / \mathrm{mL}$, respectively, and differed with a statistic significance $(p<0.001)$. The mean value of NTproBNP in the subgroup of patients with indeterminate diastolic function was $267 \pm 6.8$ $\mathrm{pg} / \mathrm{mL}$.

\section{Peak atrial strain}

The average of the peak atrial strain was calculated in patients with normal echocardiographic examination, in patients with diastolic dysfunction, and separately for each subgroup of diastolic dysfunction, and in those with indeterminate diastolic function. The values are shown in Table 2 . There is a statistically significant difference between the peak atrial strain in patients with normal echocardiographic examination vs those with diastolic dysfunction $(38.4 \pm 3.2 \%$ vs $24.9 \pm 9.3 \%(p<0.001)$. We noticed the same statistically significant difference also in the analysis by groups of diastolic dysfunction (grade I, grade II, and grade III vs normal examination, respectively: $31.2 \pm 3.4 \%$ ( $p$ $<0.05), 25.9 \pm 4.7 \%(p<0.001)$, and $18.9 \pm 3.1 \%(p<0.001)$. The group of patients with indeterminate diastolic function had the mean value of peak atrial strain (PAS) of $28.7 \pm 8.1 \%$.

\section{Relationship of the peak atrial strain with the grade of diastolic dysfunction and the value of NTproBNP}

The mean value of the peak atrial strain in the group of healthy patients was $38.4 \pm 3.2 \%$, and the mean value of NTproBNP in the same 


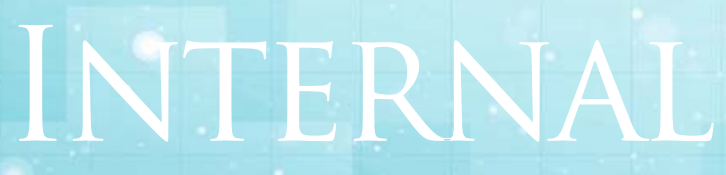

Original papers

group was $117 \pm 4.7 \mathrm{pg} / \mathrm{mL}$. The group of patients with diastolic dysfunction had a mean value of LALS and NTproBNP of $24.9 \pm 9.3 \%$ and $332 \pm 54 \mathrm{pg} / \mathrm{mL}$, respectively. Patients with indeterminable diastolic function had values of LALS and NTproBNP of $28.7 \pm 8.1 \%$ and $267 \mathrm{pg} / \mathrm{mL}$, respectively. The mean value of LALS corresponding to diastolic dysfunction of grade I, II and II was significantly lower compared to that determined in patients with normal echocardiographic examination, respectively: $31.2 \pm 3.4 \%(p<0.05), 25.9 \pm 4.7 \%(p<0.001)$, and $18.9 \pm 3.1 \%(p<0.001)$, and mean values of NTproBNP statistically significant higher, respectively: $224 \pm 5.1 \mathrm{pg} / \mathrm{mL}(p<0.05)$, $311 \pm 8.9 \mathrm{pg} / \mathrm{mL}(p<0,05)$, and $526 \pm 3.8 \mathrm{pg} / \mathrm{ml}$ $(p<0.001)$. LALS was correlated with a statistical significance with the grade of diastolic dysfunction $(r=-0.83, p<0.001)$. According to the obtained data, we chose the cut-off value for PAS of $25 \%$. Applying this value in the group with indeterminate diastolic function, we identified 21 patients with decreased values of PAS and NTproBNP statistically significantly higher compared to those with PAS > 25\%, $356 \mathrm{pg} / \mathrm{mL}$ vs 132 $\mathrm{pg} / \mathrm{mL}$, respectively $(p<0.001)$.

\section{DISCUSSIONS}

The study that we presented demonstrates the role played by the analysis of myocardial left atrial longitudinal deformation in the diagnosis of heart failure with preserved ejection fraction. The analysed data show that left atrial longitudinal strain was significantly decreased in patients with diastolic dysfunction compared to those with normal echocardiographic examination. We demonstrated that there is a statistically significant relationship between the grade of diastolic dysfunction and the values of LALS, specifically: the more severe is the diastolic dysfunction, the more decreased is LALS, respectively: $31 \%$ corresponding to grade I, $25 \%$ corresponding to grade $\mathrm{II}$, and $18 \%$ corresponding to grade III of diastolic dysfunction.

The mean values of NTproBNP were significantly increased in patients with diastolic dysfunction grade III compared to those with dysfunction grade II and grade I, respectively. Although the value of NTproBNP represents a major diagnostic criterion for heart failure, not all hospital and ambulatory laboratories determine this parameter on a routine basis. Our study shows that a value below $25 \%$ of the left atrial longitudinal strain selects patients with the highest probability to have heart failure even when diastolic dysfunction is not certain. In the performed analysis, patients with indeterminate diastolic function and atrial strain $<25 \%$ had values of NTproBNP with a diagnostic significance for heart failure. The mean value 


\begin{tabular}{|c|c|c|c|}
\hline & $\begin{array}{c}\text { Altered } \\
\text { echocardiography } \\
\mathrm{n}=147 \mathrm{p}\end{array}$ & $\begin{array}{c}\text { Normal } \\
\text { echocardiography } \\
\mathrm{n}=33\end{array}$ & $p$ value \\
\hline Age (years) & $65 \pm 11$ & $63 \pm 8$ & 0.243 \\
\hline Female/male & $76 / 71$ & $18 / 15$ & 0.717 \\
\hline BMI (kg/m ${ }^{2}$ ) & 52 & 7 & 0.583 \\
\hline Diabetes mellitus & 118 & 27 & 0.001 \\
\hline Hypertension & 74 & 4 & 0.001 \\
\hline $\begin{array}{c}\text { Coronary artery } \\
\text { disease }\end{array}$ & 63 & 7 & 0.001 \\
\hline History of atrial & 11 & $117 \pm 4.7$ & 0.001 \\
\hline fibrillation & $332 \pm 54$ & $62 \pm 6 \%$ & 0.001 \\
\hline NTproBNP (pg/mL) & $54 \pm 8 \%$ & $38 \pm 3 \%$ & 0.05 \\
\hline Ejection fraction & $25 \pm 9 \%$ & & 0.001 \\
\hline Peak atrial strain & &
\end{tabular}

Table 1. Patient characteristics in relationship with the echocardiographic examination: normal or altered (left ventricular hypertrophy, left atrial enlargement, left ventricular diastolic dysfunction)

\begin{tabular}{|c|c|c|c|c|c|}
\hline & $\begin{array}{c}\text { Normal } \\
\text { examination } \\
n=33 p\end{array}$ & $\begin{array}{l}\text { DD grade I } \\
n=32 p\end{array}$ & $\begin{array}{l}\text { DD grade II } \\
\qquad n=66 p\end{array}$ & $\begin{array}{l}\text { DD grade III } \\
n=18 p\end{array}$ & $\begin{array}{c}\text { Indeterminable } \\
D D \\
n=31 p\end{array}$ \\
\hline E wave $(\mathrm{cm} / \mathrm{s})$ & $68 \pm 10.2$ & $59 \pm 8.3$ & $57 \pm 7.8$ & $97 \pm 9.8$ & $53 \pm 7.1$ \\
\hline E/A ratio & $1.2 \pm 0.4$ & $0.7 \pm 0.2$ & $0.7 \pm 0.8$ & $2.2 \pm 1.6$ & $0.8 \pm 0.3$ \\
\hline $\begin{array}{l}\text { Septal e' } \\
(\mathrm{cm} / \mathrm{s})\end{array}$ & $10.8 \pm 3.6$ & $9.3 \pm 4.2$ & $7.5 \pm 3.2$ & $4.7 \pm 3.8$ & $7.3 \pm 3.1$ \\
\hline $\begin{array}{l}\text { Lateral e' } \\
(\mathrm{cm} / \mathrm{s})\end{array}$ & $13.1 \pm 4.1$ & $11.7 \pm 3.8$ & $8.9 \pm 3.6$ & $6.2 \pm 4.1$ & $9.2 \pm 3.2$ \\
\hline Mean E/e & $5.8 \pm 4.3$ & $6.7 \pm 3.7$ & $11.9 \pm 4.3$ & $16.3 \pm 3.8$ & $12.3 \pm 3.6$ \\
\hline $\begin{array}{l}\text { Tricuspid } \\
\text { regurgitation }\end{array}$ & $1.2 \pm 2.1$ & $2.1 \pm 1.7$ & $2.6 \pm 2.1$ & $3.2 \pm 2.2$ & $2.4 \pm 2.8$ \\
\hline
\end{tabular}

Table 2. Echocardiographical characteristics and mean values of NTproBNP in study lots 


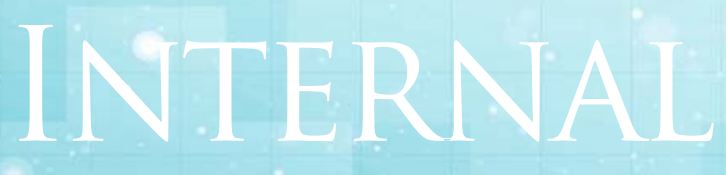

Original papers

of atrial strain in the group of patients in which HFpEF was excluded was significantly higher compared to patients with altered diastolic function (34\% vs $25 \%$ ). Recent populational studies ${ }^{(4-10)}$ demonstrated the importance of the assessment of the morphology and function of the left atrium in various cardiovascular diseases, including heart failure.

The main role of the left atrium is to modulate the ventricular filling pressure and to improve the pump performance of the left ventricle. We can distinguish three phases in the atrial cycle: the reservoir phase for venous return during the ventricular systole, the conduct phase during ventricular protodiastole, and the pump phase in ventricular tele-diastole. The three phases contribute with $40 \%, 35 \%$, and $25 \%$, respectively, to the stroke volume in healthy subjects ${ }^{(4,14,15)}$. Both left ventricular systolic dysfunction - even a subtle one - and diastolic dysfunction, particularly when it is accompanied by increased intraventricular pressures, are reflected in the reservoir function of the left atrium $^{(18)}$.

The study of Cameli et al. demonstrated via cardiac catheterisation the correlation between atrial longitudinal strain and filling pressure of the left ventricle in patients with decreased $\mathrm{EF}^{(3)}$. Another prospective study, which followed 312 patients for a mean duration of 3 years, showed that there is a significant association between LALS and the prognosis, regardless of age, cardiovascular risk factors, severity of diastolic dysfunction, ejection fraction, history of myocardial infarction or valvular disease ${ }^{(10)}$.

The same study demonstrated that the predictive value of LALS is more important that the indexed left atrial volume, suggesting that analysis of atrial dysfunction is more sensitive than morphological parameters $^{(10)}$. It was demonstrated that untreated hypertensive patients can have changes of atrial deformation even in the absence of diastolic dysfunction consistent with subclinical myocardial atrial dysfunction ${ }^{(11)}$. The same association is also present in diabetic patients with HFpEF independently of other cardiovascular risk factors $^{(12)}$.

Studies that assessed atrial function in HFpEF showed that the same factors that determine the fibrosis of ventricular subendocardial myocardial fibres also produce fibrosis of atrial myocardium and atrial remodelling that leads to the occurrence of atrial dysfunction ${ }^{(20-24)}$. Mondillo et al. ${ }^{(23)}$ showed that atrial deformation is impaired in patients with hypertension and/or diabetes mellitus who had a normal left atrium at the echocardiographical examination, suggesting that the alteration of atrial strain precedes the atrial changes diagnosed via standard examination. The 


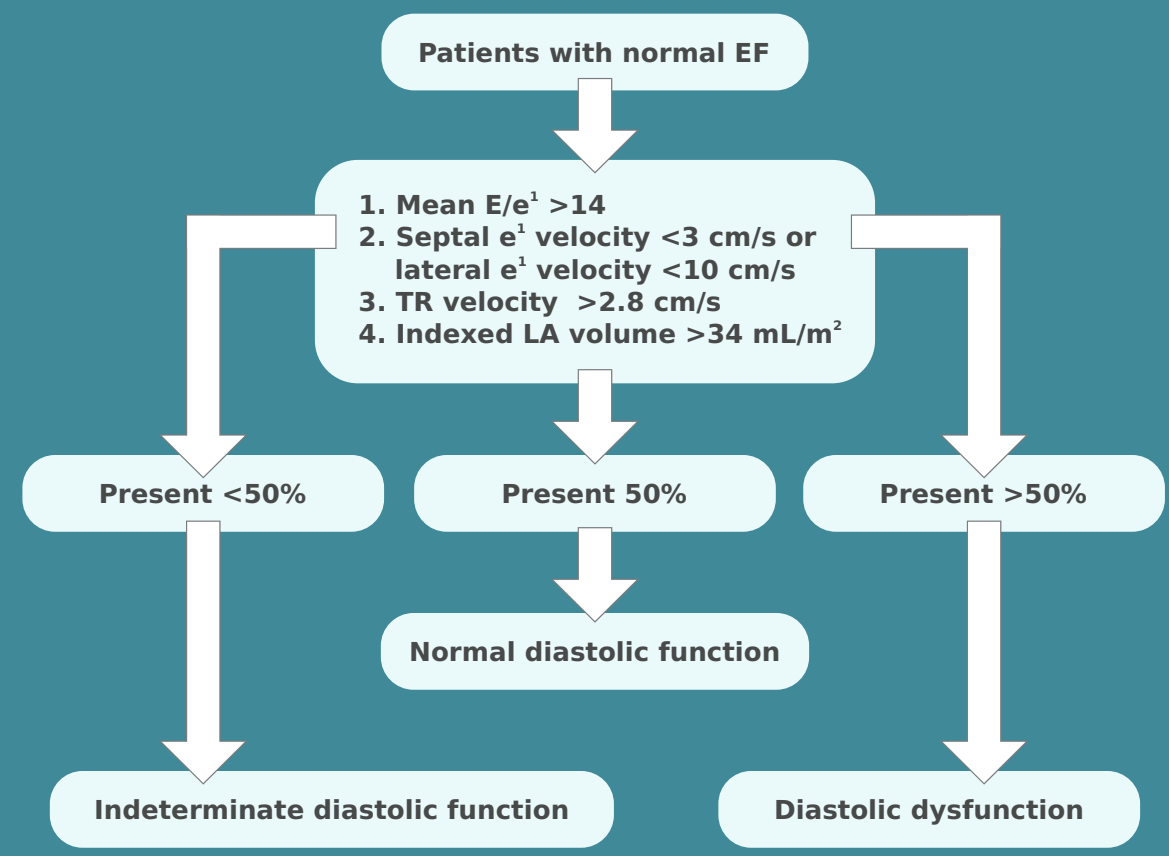

Figure 1. Algorithm for the diagnosis of or left ventricular diastolic dysfunction in subjects with normal left ventricular ejection fraction (LVEF)

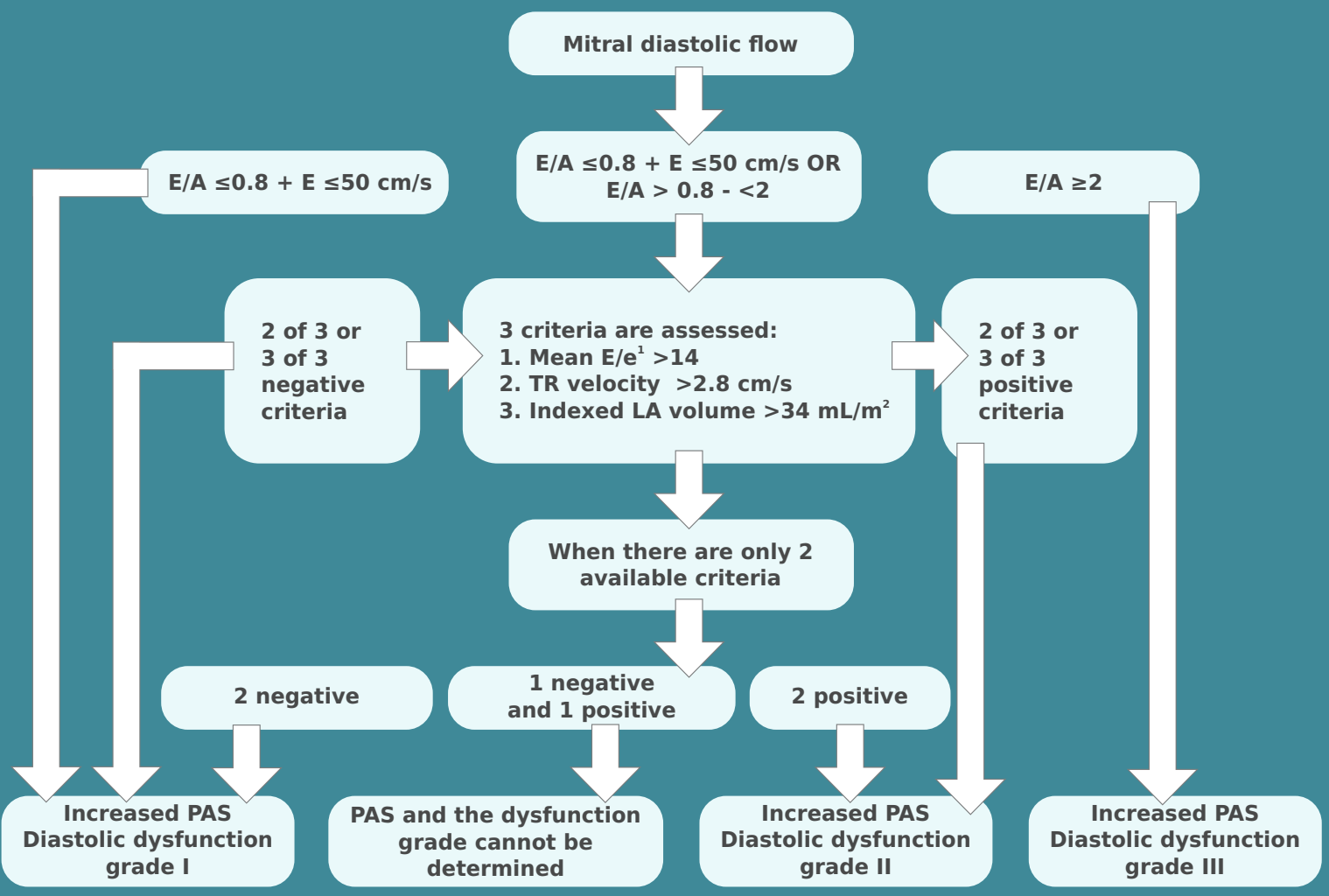

Figure 2. Algorithm for the estimation of the left ventricular filling pressures and grading of the left ventricular diastolic dysfunction in patients with decreased LVEF and in those with myocardial disease and normal LVEF after consideration of clinical data and other 2D data 


\section{INTERNAL MEDI}

\section{Original papers}

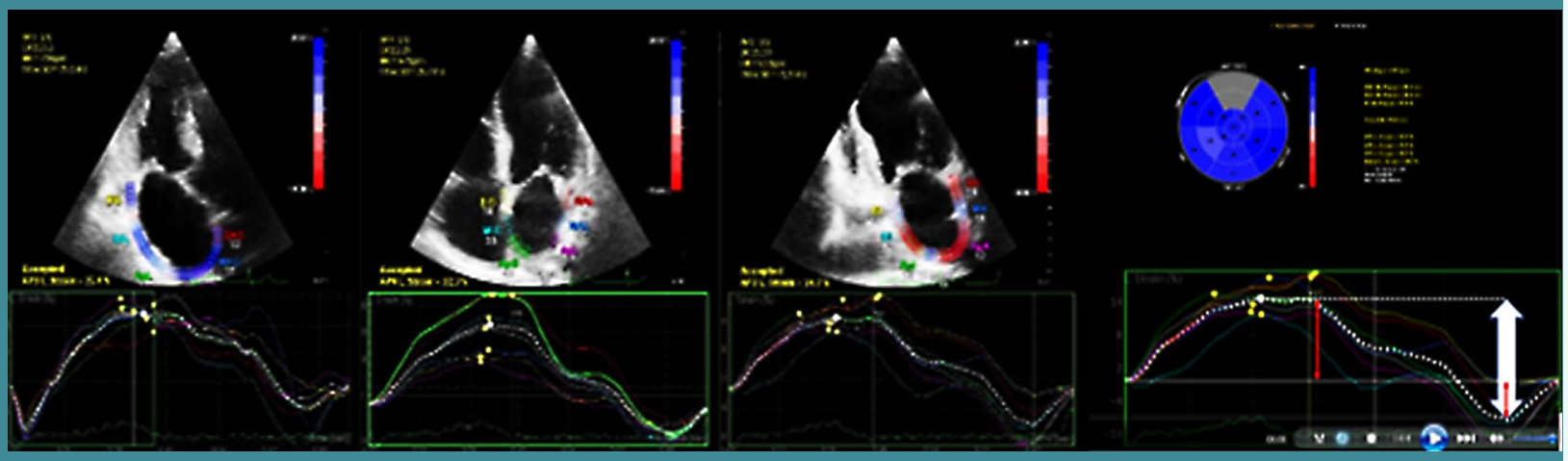

Figure 3. Assessment via 2D speckle tracking echocardiography (STE) of the atrial global longitudinal strain with reference point indicated by the $R$ wave, using the model with 15 segments analysed in apical 3, 4, and 2 chamber view, excluding the anteroseptal segments corresponding to the ascending aorta (image on the left). The image on the right represents the bull's eye graph of the atrial global strain. The segments corresponding to the aortic wall were excluded (top). Below the global strain curves for each segment are represented; the dotted white line is the mean value of the 15 segments. The thick arrow represents the strain in the reservoir phase. The thin red line superposed to the white one represents the strain in the pump phase of the atrium, and the long red arrow represents the strain in the conduct phase.

reduction of the atrial strain was also associated with the risk of occurrence and/or recurrence of atrial fibrillation, its role in predicting the risk of stroke being additive to the CHADS2 score ${ }^{(4)}$.

The study of Kuppahaly ${ }^{(19)}$ demonstrated via MRI - speckle tracking comparative analysis the role of atrial fibrosis in functional and structural atrial remodelling. The study of Leong et al. ${ }^{(9)}$ showed that the atrial strain in the reservoir phase is independently associated with the risk of cryptogenic stroke. Taking into consideration the many published evidence regarding clinical implications of the assessment of ventricular and atrial myocardial deformation, in 2011 Mor-Avi et $a l^{(14)}$.published the first ASE/EAE Consensus Statement on Methodology and Indications of Quantitative Evaluation of Cardiac Mechanics. In the document the two evaluation methods are discussed: using as reference point the $\mathrm{R}$ wave, more adequate 
for the analysis of the reservoir function, and the method which uses as reference point the $P$ wave, more adequate for the analysis of the atrial pump function (Figure 1 ).

Both methods were equally recommended for the model with two views (apical 4 chamber and apical 2 chamber), and also for the model with 3 views (apical 4, 3, and 2 chamber).

Recently in 2018 Badano et al. ${ }^{(16)}$ published a document EACVI/ASE/Industry Task Force regarding the standardization of left atrial deformation using two dimensional speckle tracking echocardiography. The apical 4 chamber view is recommended; the other two views are optional. It is considered that the ECG trigger is just a surrogate for enddiastole, respectively ventricular endsystole, and it is recommended that the measurements of the 3 phases of the atrial cycle to be performed effectively on the strain curve, corresponding to the enddiastolic peak for the reservoir phase, endsystolic for the pump phase, and calculated as difference for the conduct phase (Figure 1 ). Regarding the reference value for atrial stain, for the moment there is no consensus; this can be explained on one hand by the existence of several software packages for calculation, corresponding to the companies that manufacture the echocardiograph, and on the other hand by the different analysis methods chosen, and also the relatively low size of the study population.

A meta-analysis published in 2017 by Pathan et al. ${ }^{(15)}$ reviewed 40 studies (2542 healthy subjects) and demonstrated the following reference values: $38-41 \%$ for the reservoir function, $21-25 \%$ for the conduct function, and $16-19 \%$ for the pump function. An atrial strain below $20 \%$ proved to be an independent parameter of cardiovascular prognosis $^{(10)}$.
In our paper we assessed the reservoir function using the $\mathrm{R}$ wave as trigger and analysing the segments obtained in 3 views. The values of atrial longitudinal strain were consistent with the published ones ${ }^{(15,25)}$. We demonstrated the relationship between the severity of the diastolic dysfunction and the values of atrial strain in patients with preserved ejection fraction assessed for the suspicion of heart failure.

We extrapolated the obtained data to patients with indeterminate diastolic function and we showed that patients with atrial longitudinal strain (ALS) $<25 \%$ have significantly increased values of NTproBNP compared to those with ALS $>25 \%$, thus suggesting that the atrial strain in the reservoir phase can represent an indirect parameter for the diagnosis of diastolic dysfunction associated to heart failure with preserved ejection fraction.

\section{Limits}

Measuring of atrial strain was not performed with a dedicated program, but using the software for the analysis of the left ventricular global longitudinal strain, using the $\mathrm{R}$ wave as a reference.

We did not have a reference lot of healthy subjects. The analysed lot was heterogeneous from the point of view of the treatment (the majority were on a treatment adequate for the underlying cardiac disease, but there were also patients who were assessed prior to administration of medication).

The number of patients corresponding to the analysed subgroups was relatively low. The cut-off value of $25 \%$ was chosen following the relationship with the grade of severity of the diastolic dysfunction and the value of NTproBNP, and not following the statistical analysis. 


\section{CONCLUSIONS}

Left atrial longitudinal strain is an easy-tomeasure parameter which can help the diagnosis of left ventricular diastolic dysfunction and the assessment of its severity. In patients suspected of heart failure with preserved ejection fraction, values of ALS below $25 \%$ suggest the diagnosis and select those in whom the determination of NTproBNP is necessary, when it is not performed on a routine basis. Finally, we consider that the routine determination of the atrial longitudinal strain significantly contributes to risk stratification and refining the therapy of patients with heart diseases.

\section{References}

1. Ponikowski P, Voors A, Anker S, et al; 2016 Guidelines for the diagnosis and treatment of acute and chronic heart failure. European Heart Journal (2016) 37, $2129-2200$

2. Nagueh S, Smiseth O, Appleton C, et al; Recommendation for the Evaluation of Left Ventricular Function by Echocardiography: An Update from the American Society of Echocardiography and the European Association of Cardiovascular Imaging. European Heart Journal - Cardiovascular Imaging (2016) 17, 1321-1360

3. Cameli $M$, Lisi $M$, Padeletti $M$ et al; Left atrial longitudinal strain by speckle tracking echocardiography correlates well with left ventricular filling pressures in patients with heart failure. Cardiovascular Ultrasound 2010,8: 1-14

4. Rimbaș R, Dulgheru R, Vinereanu D; Methodological Gaps in Left Atrial Function Assessment by 2D Speckle
Tracking Echocardiography. Arq Bras Cardiol. 2015 dec: 105 (6) :625-636

5. Takemoto $Y$, Barnes $M$, Seward Jet al; Usefulness of left atrial volume in predicting first congestive heart failure in patients $\geq 65$ years of age with well preserved left ventricular systolic function. Am J Cardiol 2005 ; 96(6) : 832 - 36

6. Benjamin E, D`Agostino R, Belanger $A$ et al; Left atrial size and the risk of stroke and death. The Framingham Heart Study. Circulation 1995; 92(4): 83541

7. Gottdiener J, Kitzman D, Aurigema G et al; Left atrial volume, geometry and function in systolic and diastolic heart failure of persons $\geq 65$ years of age (the cardiovascular health study). Am J Cardiol 2006 ; 97(1): 83-9

8. Tsang T, Barnes M, Gersh Bet al; Prediction of risk for first age related cardiovascular events in an elderly population: the incremental value of echocardiography . J Am Coll Cardiol.2003; 42 (7): 1199-205

9. Leong $D$, Joyce $E$, Debonnaire Pet al; Left Atrial Dysfunction in the Pathogenesis of Cryptogenic Stroke : Novel Insights from Speckle - Tracking Echocardiography. J Am Soc Echocardiogr 2017; 30:71-9

10. Cameli M, Lisi M, Focardi $M$ et al; Left Atrial deformation Analysis by Speckle Tracking Echocardiography for Prediction of Cardiovascular Outcomes. Am J Cardiol 2012; 110:264 -269

11. Cameli M, Lisi M, Righini et al;Left Atrial Strain in Patients with Arterial Hypertension International Cardiovascular Forum Journal 2013 1:31- 36

12. Ismail L, Zafirovska, Hristovski Z; Evaluation of the role of left atrial strain using two-dimensional speckle tracking echocardiography in patients with diabetes mellitus and heart failure with preserved left ventricular ejection fraction. Dabetes \& vascular Disease Research 201613 (6) $384-394$

13. Voigt J, Pedrizzetti G, Marwick T et al; Definition for a common standard for 2 D speckle tracking echocardiography: consensus document of the EACVI IASE/ Industry Task Force to standardize deformation 
imaging European Heart Journal (2015); 16, 1-11

14. Mor-Avi V, Lang R, Badano L et al; Current and Evolving Echocardiographic Techniques for the Quantitative Evaluation of Cardiac Mechanics: ASE/EAE Consensus Statement on Methodology and Indications.J AM Soc Echocardiogr $2011 ; 24$ : 277 - 313

15. Pathan F, D 'Elia N, Nolan $M$ et al; Normal Ranges of Left Atrial Strain by Speckle Tracking Echocardiography: A Systematic Review and Meta-Analysis. J Am Soc Echocardiogr 2017; 30: 59-70

16. Badano L, Kolias T, Muraru D et al; Standardization of left atrial, right ventricular, and right atrial deformation imaging using two dimensional speckle tracking echocardiography : a consensus document of the EACVI/ASE/Industry Task Force to standardize deformation imaging .

17. Nagueh S, Smiseth O et al; Recommendation for the Evaluation of Left Ventricular Function by Echocardiography: An Update from the American Society of Echocardiography and the European Association of Cardiovascular Imaging. European Heart Journal - Cardiovascular Imaging (2018) 19, 591-600

18. Serri $K$, Reant $P$, Lafitte $M$ et al; Global and regional myocardial function quantification by two dimensional strain.J AM Coll Cardiol.2006;46(6):1175-81

19. Kuppahally S, Nazem A, Burgon Met al; left atrial strain and strain rate in patients with paroxysmal and persistent atrial fibrillation. Circulation:Cardiovascular imaging. 2010; 3:231-239

20. Morris D, Gailani M et al; Left atrial systolic and diastolic function in heart failure with normal left ventricular ejection fraction. I Am Soc Echocardiogr 2011; 24 : 651-662

21. Santos $A B$, Kraigher- Krainer $E$ et al. PARAMOUNT investigators. Impaired left atrial function in heart failure with preserved ejection fraction . Eur J Heart Fail 2014; 16:1096-1103

22. Cianciulli T, Saccheri $M$ et al; Two dimensional speckle tracking echocardiography for the assessment of atrial function. World J Cardiol 2010; 2:163-170

23. Mondillo S, Cameli M, Caputo M et al. Early detection of left atrial strain abnormalities by speckle tracking in hypertensive and diabetic patients with normal left atrial size. J Am Soc Echocardiogr 201 1; 24 : 898-908

24. Freed B, Daruwalla V, Shah $S$ et al. Prognostic Utility and Clinical Significance of Cardiac Mechanics In Heart Failure with Preserved Ejection Fraction : Importance of Left Atrial Strain . Circ Cardiovasc Imaging. 2016 Mar ,9 (3) 10.116

25. Singh A, Addetia $K$; Left Strain Categorization of LV diastolic Dysfunction JACC:Cardiovascular Imaging 2017 Jul 10(7) 735-743 